\title{
AIR QUALITY COMPARISON BETWEEN TWO MAJOR CITIES IN ROMANIA: TIMISOARA VS IASI
}

\author{
Drd. Ing. Matei Laurentiu Lordos
}

\author{
Universitatea Politehnica Timisoara, Romania, mateilordos@gmail.com
}

\begin{abstract}
The quality of air is becoming a highly important factor in our days. Today an overwhelming percentage on industry is based in the metropolitan areas. This is a reason why metropolitan areas are becoming more and more polluted. With the pollution becoming higher and higher the quality on life in general decreases in major cities.

Air quality slowly becomes a determining factor when choosing to move from city to city with the job. One example of how air pollution affects communitiesis Beijing, in the last 6 months the population decreased by approximately $0.5 \%$, the percentage isn't so big, but need to take into account that the numberof citizens always was growing in Beijing. People in our days tend to look for cleaner areas with low pollution where to have a healthier life. In my pervious paper I've talked about 2 devices that can measure following pollutants: PM2.5, PM 10 and NOx in real time, this device will be very helpful in determining the most common pollution factors in real time. What I'm trying to accomplish in this study is a comparison between two major cities in Romania, whom are big metropolitan areas and biggest industrial centers in their region. The cities that I've chose to compare are Timisoara and Iasi. Both cities have approximately the same number of inhabitants and also both of them have an emerging industry. Across this paper I will compare the traffic, industrial waste released in air, number of air quality measurement stations and where they are placed, the amount of precipitation per year and of course following pollutants: PM 2.5, PM 10 and NOx. For now, I will compare official info's from both cities. But after my device will be ready, I will go personally and measure each pollutant agent personally. I will try to determinate which of these two cities has a friendlier environment to live.
\end{abstract}

Keywords: environment, pollution, air quality, PM2.5, PM10, NOx.

\section{Geography}

Timișoara lies at an altitude of 90 meters (300 feet) on the southeast edge of the Banat plain, part of the Pannonian Plain near the divergence of the Timiss and Bega rivers. The waters of the two rivers form a swampy and frequently flooded land. Timișoara developed on one of few places where the swamps could be crossed. These constituted a natural protection around the fortress for a very long time, however, they also favored a wet and insalubrious climate, as well as the proliferation of the plague and cholera, which kept the number of inhabitants at a relatively low number and significantly prevented the development of the city. With time, however, the rivers of the area were drained, dammed and diverted. Due to these hydrographical projects undertaken in the 18th century, the city no longer lies on the Timiş River, but on the Bega canal. This improvement of the land was made irreversible by building the Bega canal (started in 1728) and by the complete draining of the surrounding marshes. However, the land across the city lies above a water table at a depth of only 0.5 to 5 meters (1.6-16.4 feet), a factor which does not allow the construction of tall buildings. The rich black soil and relatively high-water table make this a fertile agricultural region. City area has $130.5 \mathrm{~km}^{2}$ and the metropolitan area has $1570 \mathrm{~km}^{2}$. Iasi, located in the North-East of Romania, between the Iași Ridge (Romanian: CoastaIașilor) (the northern-most hill formation of the Bârlad Plateau) and the Jijia Plain, Iași used to be the crossroads place of the commercial routes that passed through Moldavia coming from Kingdom of Poland, 
Habsburg Monarchy, Tsardom of Russia and Constantinople. The city lies on the Bahlui River, a tributary of the Jijia (tributary of the Prut). The surrounding country is one of uplands and woods, featuring monasteries and parks. Iași itself stands amid vineyards and gardens, partly on hills, partly in the inbetween valley. It is a common belief that Iași is built on seven hills. [1]

\section{Climate}

Climate in this area has mild differences between highs and lows, and there is adequate rainfall year-round. The climate which defines Timișoara city is the temperateoceanic climate and can be regarded as humid continental when using an isotherm of $0{ }^{\circ} \mathrm{C}$ $\left(32{ }^{\circ} \mathrm{F}\right)$. The city characterizes the SouthEastern part of The Pannonian Basin.

Climatic general features consist of various and irregular weather conditions. The dominating temperate air masses during spring and summer are of oceanic origin and come with great precipitations. Frequently, even during winter period, the Atlantic humid air masses bring rainy and snowy weather, rarely cold weather.

Iaşi has a humid, continental-type climate with four distinct seasons. Summers are warm with temperatures sometimes exceeding 35 ${ }^{\circ} \mathrm{C}$ while winters are cold and windy with moderate snowfall and temperatures at night sometimes dropping below $-15^{\circ} \mathrm{C}$.

\section{Population and density}

Both cities are the biggest cities in their region, Timisoara in western part of Romania and Iasi in the eastern part of Romania. Also they are the major industrials centers for their geographical region. Iasi is the $2^{\text {nd }}$ most populated town in Romania after Bucharest and Timisoara is the $3^{\text {rd }}$ most populated town in country. Iasi has 371889 inhabitants with a density of $3092 / \mathrm{km}^{2}$. Timisoara has 331004 inhabitants with a density of $2447 / \mathrm{km}^{2}$. [2]

From the above numbers can be seen that this cities are the biggest metropolitan areas located in their geographical region

\section{Industry}

The economy of Timișoara has historic tradition in manufacturing, commerce, transport, education, communications and tourism. Timișoara has been an important economic center since the 18th century when the Habsburg administration was installed.

Apart from domestic local investment, there has been significant foreign investment from the European Union, particularly from Germany and Italy. Continental AG has produced tires since opening a plant in 1998 . In the years that followed, Continental also established an automotive software engineering division in Timișoara. All in all, as of 2015 Continental AG employed about 8000 people in Timișoara, and the company keeps expanding. The Linde Group produces technical gases, and a part of the wiring moulds for BMW and Audi vehicles are produced by the company Dräxlmaier Group. Wiring for Volkswagen and other vehicles are produced at the German company Kromberg\&Schubert.

Iași is an important economic center in Romania. The local and regional economy relies on industry and service sector institutions and establishments. The most important service sectors are related to education, health care, banking, research, culture, government and tourism. The city is an important information technology sector center, with the presence of several large multinational companies.

An estimated workforce of more than 35,000 employees is active in Iaşi's industrial manufacturing sector, particularly in automotive, pharmaceutical industry, metallurgical production, aerospace, industrial equipment, energy, textiles and clothing, home appliances, building materials, food industry.

\section{Means of transport}

Timişoara's public transport network consists of 9 tram lines, 9 trolleybus lines and 21 bus lines and it is operated by a company owned by the City Hall. The system covers all the important areas of the city and it also connects Timişoara with some of the communes of the metropolitan area.

In 2015, Timişoara became the first city in Romania to offer public transport by bike.

Iași's public transportation system operates an extensive network using 123 
trams (electric trams began operating in Iași in 1900) and 150 buses. An average of 140,000 passengers are using public transportation per day. From latest studies in Timisoara are 240368 registered cars and in Iasi the number of registered cars is 164576 . [3]. Both cities are historical, so they were not built to sustain such large number of cars.

The majority of their inhabitants are using their own cars to commute between home and work, because public transportation isn't reliable. So, at rush hours in both cities on the major boulevard's jams are created. Thus, resulting a higher air pollution. At any time of the day the city centers of these two cities are overcrowded with cars, due to the fact that the streets were not build to take this amount of traffic. Also, the number of cars that are transiting this city is increasing each day, due to the fact that they are on major European rods and close to state borders.

\section{Air pollution}

Timisoara doesn't have an infringement set by EU yet, but if the industry, traffic, build sites are developing in the same rate as now, in few years there will be air quality issues in Timisoara. This can be prevented if needed measures are taken.

Iași has the second-worst air quality in Romania, after Bucharest.In 2014, the European Commission started environmental law infringement procedures against Romania, citing Bucharest, Iași, and Brașov cases as examples. In 2015, atmospheric particulate matter has repeatedly reached and exceeded legal thresholds for $\mathrm{PM}_{10}$. Pollution from vehicular traffic, construction works, and a lack of green spaces (the city only has about $11 \mathrm{~m}^{2}(118 \mathrm{sq} \mathrm{ft})$ of public green spaces per capita) make up some of the reasons behind these problems.

\subsection{NOx chomparison}

Will compare NOx quantities in air from start of the year till present, for last month and for last week.[4]

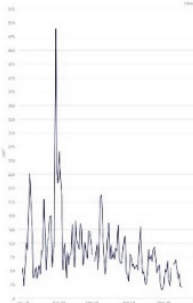

Figure 1.NOx in Iasi from year start till present.

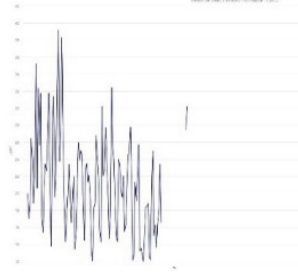

Figure 2. NOx in Timisoara from year start till present

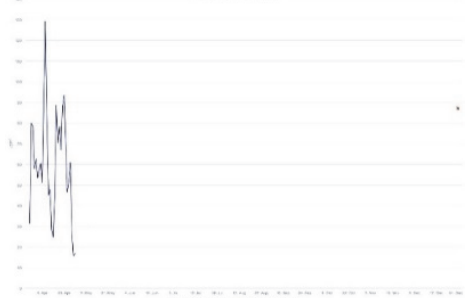

Figure 3.NOx in Iasi from last month

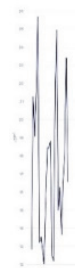

Figure 4.NOx in Timisoara from last month

Figure 5.NOx in Iasi from last week 

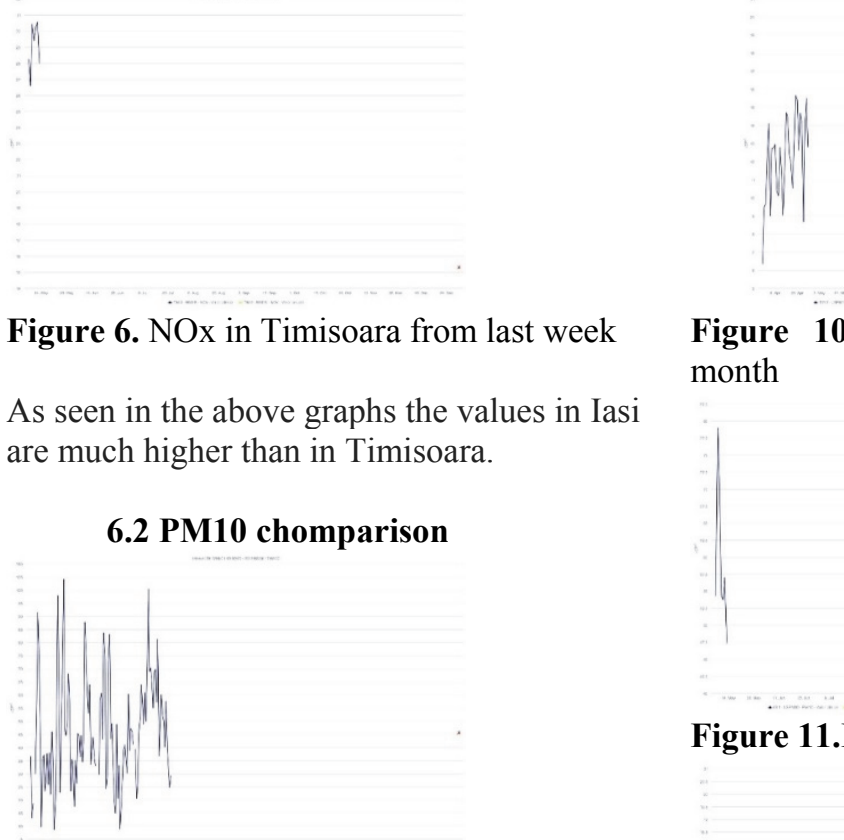

Figure 6. NOx in Timisoara from last week

Figure 10.PM10 in Timisoara from last month

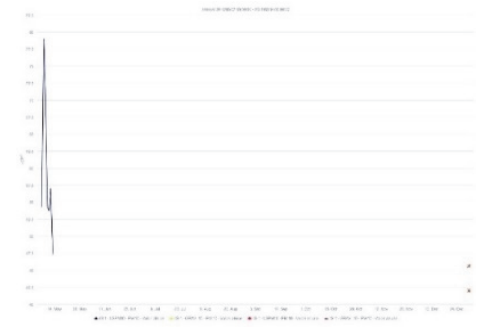

Figure 11.PM10 in Iasi from week

Figure 7. PM10 in Iasi from year start till present

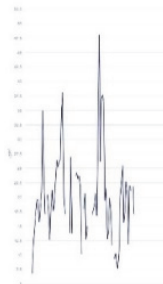

Figure 8. PM10 in Timisora from year start till present

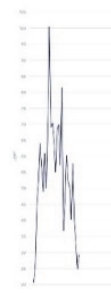

Figure 9. PM10 in Iasi from last month

\section{Figure 12.PM10 in Timisoara from last week}

Same as for NOx, PM10 values are much higher in Iasi than in Timisoara.

\subsection{PM2.5 chomparison}

Comparing values from both cities from the start of the year till present.

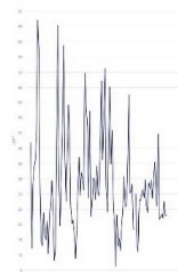

Figure 13.PM2.5 in Iasi from year start till present 


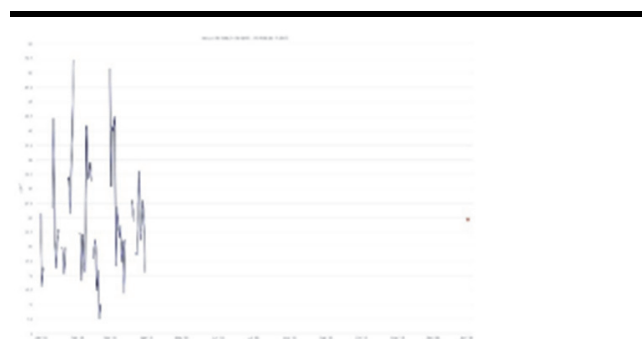

Figure 14.PM2.5 in Timisoara from year start till present

\section{Conclusion}

Compared two major cities with also the same number of people living in them, both of them are large industrial centers.

From the data that can be viewed in graphs we can reach to the conclusion that the air in Iasi is much more polluted then in Timisoara.

\section{Acknowledgment}

This paper has been conceived in the frame of my Phd program, at the Politehnica University of Timisoara. I am grateful to my adviser and the Doctoral school for the support. Thanks to the congress organisers and appreciations to the anonymous referees.

\section{References}

[1] https: //en.wikipedia.org

[2] http:

//www.monitorulcj.ro/economie/61894analiza-cele-mai-populate-ora $\% \mathrm{C} 5 \% 9 \mathrm{Fe}$ din-romania-in-2017-clujul-dep $\% \mathrm{C} 4 \% 83$ sitde-iasi-si-timisoara\#sthash.CZPAaTeE.dpbs

[3] http: //www.analizeeconomice.ro/2018/02/topuljudetelor-dupa-numarul-de.html

[4] http: //www.calitateaer.ro 